\title{
New Paradigm for Certificate of Inheritance Regulation as the Basis of Land Rights Transfer
}

\author{
Dinda Keumala \\ \{dinda.k@trisakti.ac.id\} \\ Universitas Trisakti, Jakarta, Indonesia
}

\begin{abstract}
Certificate of inheritance is a requirement to register land rights transfer in case of inheritance. The background of this research is to acknowledge the regulation of certificate of inheritance periodization in Indonesia and the legal consequences of certificate of inheritance issuance as stated in Law Article 111 (1) c Number 4, 5, and 6, Permen ATR Number 16 of 2021. The types of research utilized in this writing are normative research and descriptive analytic research. The regulation of certificate of inheritance in Indonesia is divided into 3 (three) periods namely initial period as stated by Decree of Directorate General of Agrarian (Head of Directorate of Land Registration) Number: DPT/12/63/12/69 dated 20 December 1969, second period as stated in Law Article 111 (1) c PMNA Number 3 of 1997, and third period as stated in Law Article 111 (1) Permen ATR Number 16 of 2021. The legal consequences of the issuance of Law Article 111 (1) c number 4, 5, and 6, Permen ATR Number 16 of 2021 regarding Certificate of Inheritance is that the regulation applies regardless any distinction in population classification, the heirs are given a freewill to choose any type of certificate of inheritance, the deed of inheritance rights issued when the testator passed away has similar status with the ones issued due to disputes, and certificate cancellation can be submitted to the General Court, Religious Court and State Administrative Court.
\end{abstract}

Keywords: New Paradigm; Certificate of Inheritance; Land Rights Transfer

\section{Introduction}

\subsection{Research Background}

Land rights transfer from one party to the other can occur due to automatic transfer of rights or by request of rights transfer. Automatic right switching refers to a situation where the legal land owner passed away through inheritance. Land rights transfer in this case happens as a consequence of law. On the other hand, land rights transfer by request occurs when the legal land owner deliberately request other party to obtain the land rights, for example due to land buying or selling activities, barter, grants, or inheritance [1].

Land inheritance refers to the transfer of rights from legal land owner to another party of their heir because the legal land owner has passed away [2]. Regarding the party that can be categorized as legal heir is regulated in the applicable Civil Law (explanation of Article 42 
Paragraph (1) of [3]. The inheritance process is categorized as law event that must be registered in Land Registration activities, because even though the inheritance process happens automatically by law because of the death of the inheritor, the transfer process must be registered on Land Rights Certificate in Land Registration Office as a sequence of events as part of data maintenance.

Rights transfer registration due to inheritance event is obligatory to ensure land registration administrative order, so that the required data can be stored and presented at Land Registration Office are always up to date [3]. Furthermore, as regulated in Law Article 42 (1) Government Regulation Number 24 of 1997 (PP Number 24 of 1997) regarding Land Ownership Registration, land rights transfer due to inheritance for registered (certified) land, must include the related land certificate, certificate of death of the initial land owner, and proof of heir.

Proof of heir is regulated in Law Article 111 (1) c Regulation of Agrarian and Landscape/Head of National Land Agency of Indonesian Republic Number 3 of 1997 regarding Provisions for the Implementation of PP Number 24 of 1997 (PMNA Number 3 of 1997) which have been amended several times, most recently by Regulation of the Minister of Agrarian Affairs and Spatial Planning/Head of the National Land Agency of the Republic of Indonesia Number 16 of 2021 (Permen ATR Number 16 of 2021), should include:

a. Testament of the inheritor;

b. Court's Decision;

c. Judge/Chief of the Court of Law's Decision;

d. Affidavit of Heir produced by heirs witnessed by at least 2 (two) witnesses and also acknowledged by Village Head/Headman where the inheritor lived prior to his/her death;

e. Deed of Inheritance Rights made by Notary domiciled at the region where the inheritor passed away; or

f. Certificate of Inheritance from the Hall of Heritage.

The regulations of proof of right as heir is highly interesting because on its initial version, Law Article 111 (1) c number 4 PMNA Number 3 of 1997, which was first issued, Proof of Inheritance was determined based on their population group in Indonesia as regulated in Law Article 163 Indische Staatsregeling that categorized Indonesian people into 3 groups namely European group, Foreign East group, and Indigenous group. The Foreign East group was also divided into Chinese Foreign East and non-Chinese Foreign East group. On the hand, as regulated in Law Article 131 Indische Staatsregeling different types of Civil Law regulated different result for each category as mentioned in Law Article 163 Indische Staatsregeling.

The existence of initial regulation of Law Article 111 (1) c number 4 PMNA Number 3 of 1997 which still requires proof of heir based on their population group is contradicting with Indonesian Constitution Law Article 27 (1) in conjunction with Article 28D (1). Article 27 (1) Indonesian Constitution regulates that every citizen is equal in the face of law and the government is obligated to uphold the law with no exception. On the other hand, Article 28D (1) Indonesian Constitution states that every citizen deserves to be recognized, ensured, protected and equal in the face of law.

The application of proof of heir based on population group is also contradictive with Law Number 12 of 2006 regarding Indonesian Citizenship and Law Number 23 of 2006 regarding Citizenship Administration as amended by Law Number 24 of 2013. Both of these laws state that Indonesian Citizens consist of genuine citizen and other people from another country that are confirmed to be Indonesian citizen by law.

Permen ATR Number 16 of 2021 does not significantly change the actual form of proof of heir which were previously regulated in the same chapter for each of population group, however the redaction in Article 111 (1) c Number 4, 5 and 6 Permen ATR Number 16 of 
2021 erased the term "population group" which was stated in the previously version of Article 111 (1) c Number 4 PMNA Number 3 of 1997, which resulted that proof of heir as mentioned in Article 111 (1) c Number 4, 5 and 6 Permen ATR Number 16 of 2021 applicable to every Indonesian citizen without population group category applied.

The different periodization of proof of heir regulation and certificate of heir law consequences as stated in Article 111 (1) c Number 4, 5 and 6 Permen ATR Number 16 of 2021 has brought great interests for the authors to raise the theme in an article titled "New Paradigm for Certificate of Inheritance Regulation As The Basis of Land Rights Transfer."

\subsection{Research Problems}

The research problems are:

a. How is the regulation periodization of Certificate of Inheritance in Indonesia?

b. What is the law consequences of the implementation of Certificate of Inheritance as stated in Article 111 (1) c Number 4, 5 and 6 Permen ATR Number 16 of 2021 ?

\subsection{Writing Objective}

The objectives of this article are to:

a. Provide a clear picture of regulation periodization of Certificate of Inheritance in Indonesia.

b. Provide a clear picture of law consequences of Certificate of Inheritance implementation as stated in Article 111 (1) c Number 4, 5 and 6 Permen ATR Number 16 of 2021.

\section{Research Method}

To indicate and discover the answer of the previously mentioned research problems, authors utilized the required research procedure and technique which also known as research method. The selection and utilization of the research method is aimed to optimize the obtained data and fact analysis process based on related type and nature of research Based on that, the research method can be defined as means or processes to check and investigate by using an analytical and logical thinking measure, based on certain backgrounds, formulation and theories to verify and test the actual truth of certain hypothesis regarding natural phenomenon, social phenomenon, and law phenomenon [4].

The essence of a research method in every law research is to describe the way or technique to apply the law research itself. The way or technique usually includes explanation on the research type or method, research nature, type of data, data collection tool, analysis and technique to produce research conclusion [5]. Basically, the utilization of a method in a research activity is aimed to learn one specific or a number of phenomenon and analyze them into facts, which would give solutions towards problems caused by those facts [6].

The utilized research type is a normative law research type or literature study, which is a law research, conducted by researching literature sources or secondary data sources [6]. Normative law research can be focused on law basics, law systematics, vertical and horizontal synchronization level, law history, or comparison of laws. In this research, the authors were trying to focus on the history of the implementation of Certificate of Inheritance as regulated in Article 111 (1) c Number 4 PMNA Number 3 of 1997 which has been amended for a number of times, lastly with Permen ATR Number 16 of 2021. 
Based on its nature, researches can be categorized into three different types, namely explorative research, descriptive research and explanatory research [7]. A research is categorized as a descriptive research because it can provide the most detailed data regarding human, events, or any other social symptoms. The goal is to clarify research hypotheses to help strengthen initial theories or in order to discover new theories [8].

The utilized data in this research are categorized as secondary data. Secondary data were collected from documentary study and internet sources. Data from documentary study and internet sources were gathered through substance or content analysis of data gathered by authors. Secondary data sources in this research consist of [9]:

a. Primary law materials, which are constricting law materials that consist of Indonesian Constitution 1945, Law Number 2 of 1986 concerning General Courts as amended several times, first by Law Number 8 of 2004 and lastly by Law Number 49 of 2009, Law Number 5 of 1986 concerning State Administrative Courts as stipulated has been amended by Law Number 51 of 2009, Law Number 7 of 1989 concerning Religious Courts as amended several times, first by Law Number 3 of 2006 and lastly by Law Number 50 of 2009, Law Number 30 of 2004 concerning Notary Position as amended by Law Number 2 of 2014, Law Number 12 of 2006 concerning Citizenship, Law Number 23 of 2006 concerning Population Administration as amended by Law Number 24 of 2013, Law Number 12 of 2011 concerning the Establishment of Legislation, PP Number 24 of 1997, PMNA Number 3 of 1997 which has been amended several times, most recently by Permen ATR Number 16 of 2021, and Article 131 in conjunction with Article 163 Indische Staatsregelings.

b. Secondary law materials, which are law materials that provide explanations of primary law materials, namely academic products of law experts such as books, magazines and scientific articles. In this research we also included data gathered from the internet.

c. Tertiary law materials, which are materials that provide guidance or explanations regarding primary and secondary law materials such as dictionary, encyclopedia, bibliography, cumulative index and other type of materials. In this research, we do not utilize tertiary law materials.

Data analysis utilized in this research is a qualitative analysis because qualitative data does not come with a form of numeric data [10]. Conclusion taken in this research was produced with a deductive method, which is a method to draw specific conclusions from general statements.

\section{Findings and Discussion}

\subsection{Periodization of Certificate of Inheritance Regulation in Indonesia}

Certificate of Inheritance is one of the important requirements for registering the transfer of rights due to inheritance at the Land Office. In the history of the arrangement, the Certificate of Inheritance is divided into several periodizations as follows:

\section{a) First Period}

The first period begins with the entry into force of the Agrarian Law Improvement (ALI) from 1960 to the 1970s. In this first period, the regulation of laws in the field of Agrarian Law still seemed to have a strong populist orientation as legislation intended to provide legal protection and certainty as well as justice for the community, especially those working in the 
agricultural sector (regulations on land reform). Likewise, efforts are made to provide legal certainty in the form of land registration [11].

The regulation governing Land Registration in the first period is Government Regulation Number 10 of 1961 (PP Number 10 of 1961). The provisions of Article 23 PP Number 10 of 1961 regulates:

1. "For registration of the transfer of rights due to inheritance concerning land that has been recorded, the Head of the Land Registration Office must submit a certificate of title to the land along with a will and if there is no will, a certificate of inheritance from the competent authority.

2. After the transfer of rights is recorded in the register of the land book concerned and on the certificate, the certificate is returned to the heirs, after the Head of the Land Registration Office has submitted a certificate regarding the settlement of land tax until the death of the testator."

Article 23 (1) of the PP Number 10 of 1961 does not explain the definition of certificate of inheritance and which agency is authorized to produce it. The explanation of the certificate of proof as a new heir is contained in the Letter of the Director General of Agrarian Affairs (Head of the Directorate of Land Registration) Number: DPT/12/63/12/69 dated December 20, 1969 regarding Certificate of Inheritance and Proof of Citizenship, that those who are entitled to issue a certificate of inheritance based on the classification of the population in Indonesia, namely:

1. For European population groups, a certificate of inheritance is made by a Notary.

2. For indigenous groups the inheritance certificate is witnessed by the Village Head and acknowledged by Sub District Head.

3. For the Foreign East Chinese resident group, a certificate of inheritance is made by a Notary.

4. For other East-Foreign population groups, a certificate of inheritance is made by the Heritage Hall.

For all population groups, District Court Decisions can also applicable [12].

\section{b) Second Period}

The second period of regulation of inheritance certificates begins with the issuance of PP Number 24 of 1997. This Government Regulation revokes the enactment of PP Number 10 of 1961 which regulates the same thing. The issuance of PP Number 24 of 1997 was motivated by the awareness of the increasingly important role of land in development which increasingly requires the support of legal certainty in the land sector. Normatively, legal certainty requires the availability of a set of laws and regulations that are operationally capable of supporting its implementation. Empirically, the existence of laws and regulations needs to be implemented consistently and consistently by supporting human resources [13]. PP Number 24 of 1997 does not specifically stipulate the certificate of proof as an heir. The certificate of proof as an heir is specifically stated in Article 111 (1) c of the PMNA Number 3 of 1997. The contents of Article 111 (1) c of the PMNA Number 3 of 1997 regulates the certificate of proof as an heir or certificate of inheritance consists of:

1. Will of the inheritor, or

2. Court Decision, or

3. Verdicts of Judge/Head of Court, or for original Indonesian Citizen: Certificate of Inheritance made by the inheritor should be witnessed by 2 (two) witnesses and confirmed by the Head of the Village and Head of Sub District where the heir resides at the time of 
death; for Indonesian citizen which are also Chinese descendant: Certificate of Inheritance made by a Notary; for Indonesian citizen which are also descendant of other foreign eastern countries: Certificate of Inheritance issued by Inheritance Hall.

\section{c) Third Period}

The third period of Certificate of Inheritance regulation occurred with the issuance of the Permen ATR Number 16 of 2021 which was the third amendment of the PMNA Number 3 of 1997 which comes into force on August 23, 2021. Permen ATR Number 16 of 2021 amends the provisions of Article 111 (1) c of the PMNA Number 3 of 1997, so that the certificate of proof as heirs consists of:

1. Will from inheritor;

2. Court Decision;

3. Verdicts of Judge/Head of Court;

4. Certificate of Inheritance made by the inheritor should be witnessed by 2 (two) witnesses and confirmed by the Head of the Village and Head of Sub District where the heir resides at the time of death;

5. Certificate of Inheritance made by a Notary;

6. Certificate of Inheritance issued by Inheritance Hall.

3.2 The Legal Consequences of the Enactment of the Certificate of Inheritance as Stated in Article 111 (1) c Numbers 4, 5 and 6 of the Permen ATR Number 16 of 2021

With the enactment of the Inheritance Certificate as stated in Article 111 (1) c numbers 4, 5 and 6 of the Permen ATR Number 16 of 2021, the legal consequences that occur are:

\section{a) Generally, Certificate of Inheritance is applicable for every Indonesian citizen without population group categorization}

According to the provisions stipulated in Article 7 of Law Number 12 of 2011 regarding the Establishment of Legislations, the type and order of legislation consists of:

1. Indonesian Constitution 1945;

2. Decree of the People's Consultative Assembly;

3. Laws/Government Regulations in Lieu of Laws;

4. Government Regulation;

5. President Regulation;

6. Provincial Area Regulation; and

7. Regency/City Regional Regulation.

This is in line with Hans Kelsen's theory that legal norms are tiered and layered in a hierarchy (organization), in the sense that a lower norm applies, originates and is based on a higher norm, while a higher norm applies. High norms apply, sourced and based on even higher norms, and so on until a norm that cannot be traced anymore and is hypothetical and fictitious, namely the basic norm (grundnorm) ([14] as cited in [15]). The law is arranged in one level, meaning that the higher statutory regulations are the source of lower statutory regulations and lower statutory regulations must not conflict with higher regulations [16].

The arrangement of Certificate of Inheritance as stated in Article 111 (1) c Numbers 4, 5 and 6 of the Permen ATR Number 16 of 2021 is vertically in accordance with several laws and regulations as follows: 
1. Article 27 (1) of the 1945 Constitution which stipulates that "all citizens are equal before the law and the government are obliged to uphold the law and the government with no exceptions."

2. Article $28 \mathrm{D}$ (1) of the 1945 Constitution which stipulates that "everyone has the right to recognition, guarantees, protection and fair legal certainty and equal treatment before the law."

3. Article 2 of Law Number 12 of 2006 regarding Citizenship which stipulates that "those who become Indonesian citizens are native Indonesians and people of other nationalities ratified by law as citizens."

4. Article 1 point 3 in conjunction with Article 106 of Law Number 23 of 2006 regarding Population Administration as amended by Law Number 24 of 2013.

The provisions of Article 1 point 3 of Law Number 23 of 2006 regarding Population Administration as amended by Law Number 24 of 2013 states that "Indonesian citizens are people of the original Indonesian nation and people of other nationalities ratified as Indonesian citizen by law."

Meanwhile, the provisions of Article 106 of Law Number 23 of 2006 regarding Population Administration as amended by Law Number 24 of 2013 revoke and declare no longer valid:

1. "Book One, Second Chapter, Second Part and Third Chapter of the Civil Code (Burgerlijk Wetboek voor Indonesie, Staatsblad 1847:23);

2. Civil Registration Regulations for European Class (Reglement op het Holden der Registers van den Burgerlijken stand voor Europeanen, Staatsblad 1849:25 as lastly amended with Staatsblad 1946:136);

3. Civil Registration for Chinese Class (Bepalingen voor Geheel Indonesie Betreffende het Burgerlijken Handelsrecht van de Chinezean, Staatsblad 1917:129 jo. Staatsblad 1939:288 as lastly amended with Staatsblad $1946: 136)$;

4. Civil Registration for Indonesian Class (Reglement op het Holden van de Registers van den Bugerlijeken Stand voor Eenigle Groepen v.d nit tot de Onderhoringer van een Zelfbestuur, behoorende Ind.Bevolking van Java en Madura, Staatsblad 1920:751 jo. Staatsblad 1927 : 564);

5. Civil Registration for Indonesian Christian Class (Huwelijksordonantie voor Christenen Indonesiers Java, Minahasa en Amboeina, Staatsblad 1933 : 74 jo. Staatsblad 1936:607 as lastly amended with Staatsblad 1939:288);

6. Law Number 4 of 1961 regarding Change or Addition of Family Names (State Gazette of 1961 Number 15, Supplement to State Gazette Number 2154).”

\section{b) The heirs have the freedom to choose the type of preferred Certificate of Inheritance}

Based on the provisions stipulated in Article 111 (1) c Numbers 4, 5 and 6 of the Permen ATR Number 16 of 2021, the heirs have the freedom to choose the preferred type of Certificate of Inheritance. If it turns out that there are many heirs who prefer to make a Statement of Heirs made by the heirs themselves in the presence of 2 (two) witnesses and it is known by the head of the village and sub-district where the heir lives at the time of death on the grounds that the letter is more efficient and more economical, the local Land Office may not refuse the Declaration Letter of the Heirs for registration of inheritance transfer of lands, even though the Declaration of Heirs only has the character of an underhand letter which has the power of proof as long as the parties who made it admit it.

The existence of conformity between regulations and the implementation of these regulations is one element of legal certainty that must exist according to Lon Fuller [17]. 
Meanwhile, according to Gustav Radbruch, legal certainty is certainty because of the law, and certainty in or from the law. Guaranteeing legal certainty is the main function of the law. Laws that succeed in guaranteeing a lot of certainty in social relations are useful laws. While certainty in or from the law is achieved if the law is as much as law, a law, in that law there are no conflicting provisions (the law is based on a logical and definite system). The law is made based on legal reality (rechtswerkelijheid) and the law does not contain legal terms that can be interpreted differently [18].

c) A notary can only make a deed of inheritance rights from an heir who at the time of death has the same domicile as the notary

In addition to the provisions stipulated in Article 111 (1) c Number 5 of the Permen ATR Number 16 of 2021, the authority of a Notary in making a Deed of Inheritance Rights is based on the provisions stipulated in Article 15 (1) of Law Number 30 of 2004 concerning Notary Positions as amended by Law Number 2 of 2014: "Notaries are authorized to make authentic Deeds regarding all actions, agreements, and stipulations required by laws and regulations and/or desired by interested parties to be stated in authentic Deeds, guarantee certainty of the date of making the Deed, save the Deed, provide gross, copies and quotations of the Deed, all of this as long as the making of the deed is not assigned or excluded to other officials or other people stipulated by law."

Previously in Article 111 (1) c number 4 PMNA Number 3 of 1997 stipulates that Notaries make a deed of inheritance rights for the Chinese group. only, while in the provisions of Article 111 (1) c number 5 Permen ATR Number 16 of 2021 regarding the Third Amendment to the PMNA Number 3 of 1997 stipulates that the authority of a Notary to make a deed of inheritance rights can only be carried out for an heir who at the time of death was domiciled in the same place of residence as the Notary, so that if there are heirs who request a make a deed of inheritance right of the testator who at the time of death has a different position from the position of the notary, the notary must refuse to make the deed of inheritance rights because it is outside his authority.

\section{d) In case of a dispute, the cancellation of the Certificate of Inheritance can be submitted to the General Court, Religious Court and the State Administrative Court}

If there is a dispute regarding the Statement of Heirs made by the heirs in the presence of 2 (two) witnesses and known by the village head and sub-district head where the heir resides at the time of death or a dispute regarding the certificate of inheritance rights from a notary who is domiciled at the place of residence of the testator at the time of death, it can be submitted to the scope of the general court and the religious court. The provisions of Article 50 of Law Number 2 of 1986 regarding General Courts as amended several times, first by Law Number 8 of 2004 and lastly by Law Number 49 of 2009 stipulates that" the District Court has the duty and authority to examine, decide and settle criminal cases and civil cases at the first level." Based on these provisions, if there is a dispute regarding the certificate of inheritance, it can be resolved through the District Court.

Inheritance law that applies to Muslim is Islamic Inheritance Law and it is not allowed to choose inheritance law other than Islamic Inheritance Law in accordance with the General Elucidation of Law Number 3 of 2006 regarding Amendments to Law Number 7 of 1989 regarding Religious Courts that the sentence contained in the general explanation of Law Number 7 of 1989 regarding the Religious Courts which states "The parties may consider 
choosing what law to use in the distribution of inheritance before litigation" is declared deleted.

Law Number 7 of 1989 concerning Religious Courts as amended several times, first by Law Number 3 of 2006 and lastly by Law Number 50 of 2009 in Article 49 regulates that: "The Religious Courts have the duty and authority to examine, decide and settle cases at the first level between people who are Muslim in the field of: marriage; inheritance; will; grants; wakaf; zakat; infaq; shadaqah; and Sharia Economy."

In the explanation of Article $49 \mathrm{~b}$ of Law Number 7 of 1989 regarding the Religious Courts which has been amended several times, most recently with Law Number 50 of 2009 the definition of "inheritance" is "the determination of who becomes the heir, determination of inheritance, determination of inheritance the share of each heir, and carry out the distribution of the inheritance, as well as a court order at the request of a person regarding the determination of who becomes the heir, the determination of the share of each heir."

Based on the explanation, Religious Court is able to produce the following products:

1. Verdicts, in case of a dispute between 2 opposite parties (plaintiff and defendant);

2. Decision, if there is no dispute but there is only 1 applicant. Applicant can submit application letter signed by applicant or his/her legal representative to Head of Religious Court that includes the applicant's address [19].

As an institutional structure, Inheritance Hall is a government institution (executive) under the scope of Indonesian Ministry of Law and Human Rights, so that it can be categorized as an Official or State Administration Agency in accordance with the provisions of Article 1 Number 8 of Law Number 5 of 1986 regarding The State Administrative Court as amended by Law Number 51 of 2009 which has the authority to issue (beschikking) concrete, final, and individual decision or decision in accordance with Article 1 Number 9 of Law Number 5 of 1986 regarding The State Administrative Court as amended by Law Number 51 of 2009, so that if there is a problem related to the Certificate of Inheritance issued by Inheritance Hall, then the heirs can resolve it through the State Administrative Court, and includes the Certificate of Inheritance as evidence of Civil Law, which is made by State Administrative Officials who are subject to administrative law, this is included in the form of legal disharmony that must be ended, so that the Inheritance Hall should not have the authority to issue Certificate of Inheritance [20].

\section{Conclusions}

The conclusions obtained are as follows:

a. Certificate of Inheritance Regulations are divided into 3 (three) periods:

1) The first period of Certificate of Inheritance Provisions is regulated in Letter of the Director General of Agrarian Affairs (Head of the Directorate of Land Registration) Number: DPT/12/63/12/69 dated 20 December 1969 concerning Certificate of Inheritance and Proof of Citizenship, states that the legalized institutions to issue Certificate of Inheritance based on population groups are:

a) For European Class Citizen, Certificate of Inheritance is issued by a Notary.

b) For indigenous Indonesian Citizen, Certificate of Inheritance is issued by Head of Village, acknowledged by Head of Sub District.

c) For East Foreign Chinese Class Citizen, Certificate of Inheritance is issued by a Notary. 
d) For other East Foreign Citizen, Certificate of Inheritance is issued by Inheritance Hall.

For all groups, Certificate of Inheritance can also be replaced with State Court Decision [12].

2) Second Period of Certificate of Inheritance Provision is regulated in Article 111 (1) c PMNA Number 3 of 1997 that what can be used as proof of ownership as heirs are::

a) Will of Inheritor, or

b) Court Decision, or

c) Verdicts of Judge/Head of Court, or

d) for original Indonesian Citizen: Certificate of Inheritance made by the inheritor should be witnessed by 2 (two) witnesses and confirmed by the Head of the Village and Head of Sub District where the heir resides at the time of death; for Indonesian citizen which are also Chinese descendant: Certificate of Inheritance made by a Notary; for Indonesian citizen which are also descendant of other foreign eastern countries: Certificate of Inheritance issued by Inheritance Hall."

3) Third Period of Certificate of Inheritance Provision as regulated in Article 111 (1) c Permen ATR Number 16 of 2021 which is the third amendment of PMNA Number 3 of 1997 as proof of heir consists of:

a) Will from inheritor;

b) Court Decision;

c) Verdicts of Judge/Head of Court;

d) Certificate of Inheritance made by the inheritor should be witnessed by 2 (two) witnesses and confirmed by the Head of the Village and Head of Sub District where the heir resides at the time of death;

e) Certificate of Inheritance made by a Notary resident in region at the time of inheritor death;

f) Certificate of Inheritance issued by Inheritance Hall.”

b. The legal consequences of the provision of Certificate of Inheritance as regulated in Article 111 (1) c number 4, 5 and 6 Permen ATR Number 16 of 2021 are:

1) Certificate of Inheritance is applicable for every Indonesian Citizen by no longer including population group categorization as requirement.

2) The heirs have their freedom to choose the preferred type of Certificate of Inheritance.

3) A notary can only make a deed of inheritance rights from an inheritor who at the time of death has the same domicile as the notary.

4) In the event of a dispute, Certificate of Inheritance can be submitted to legal court, religious court, and State Administrative Court.

The suggestions is that Land Registration Office should not refuse proof of heirs to provide legal certainty in any kind of forms made by heirs as long as the proof has already fulfill regulations mentioned in Article 111 (1) c number 4, 5, and 6 Permen ATR Number 16 of 2021 to accelerate land registration program in general and to accelerate land registration due to inheritance in specific.

\section{References}

[1] B. Harsono, Indonesian Agrarian Law: History of Agrarian Basic Law Formation, 
Content and Implementation. Jakarta: Djambatan, 2003.

[2] U. Santoso, Land Rights Acquisition. Depok: Kencana, 2017.

[3] The Republic of Indonesia, Government Regulation Number 24 Year 1997 Regarding Land Registration. 1997.

[4] C. F. . S. Hartono, Law Research in Indonesia at The End of the 20th Century. Bandung: Alumni, 1994.

[5] B. Waluyo, Law Research in Practice. Jakarta: Sinar Grafika, 1996.

[6] S. Soekanto and S. Mamudji, Normative Law Research: A Brief Review. Jakarta: Raja Grafindo Persada, 2007.

[7] S. H.S and E. S. Nurbani, The Implementation of Law Theory on Thesis and Dissertation Researches. Jakarta: Raja Grafindo Persada, 2013.

[8] S. Soekanto, Introduction to Law Research. Jakarta: UI Press, 2010.

[9] S. Soekanto and S. Mamuji, Normative Legal Research. Jakarta: PT Grafindo Media Pratama, 2010.

[10] M. Musa and T. Nurfitri, Research Methodology. Jakarta: Fajar Agung, 1988.

[11] M. S. W. Sumardjono, Land in Social and Cultural Economic Perspectives. Jakarta: Kompas, 2009.

[12] A. P. Parlindungan, Varieties of Agrarian Law. Bandung: Alumni, 1984.

[13] M. S. W. Soemardjono, "Law Certainty and Protection in Land Registration", Paper, "National Seminar of New Land Registration Policy and Related Taxes: A Socialization Process and Challenges." Yogyakarta, p. 1, 1997.

[14] H. Kelsen, General Theory of Law and State. New York: Russell \& Russell, 1945.

[15] F. I. S and Maria, Law Science 1: Types, Functions, and Content Materials. Yogjakarta: PT Kanisius, 2007.

[16] M. Siahaan, "Testing the Constitutionality of Our Country's Legislation: Problems and Challenges,” J. Konstitusi Sekr. Jenderal Mahkamah Konstitusi, vol. 7, no. 4, 2010.

[17] A. Ali, Revealing Legal Theory and Court Theory (Judicialprudence) Including Interpretation of Law (Legisprudence) Volume 1: Basic Understanding. Jakarta: Kencana, 2009.

[18] E. Utrecht, Introduction to Indonesian Law. Jakarta: Balai Buku Ichtiar, 1959.

[19] "Het Herzien Inlandsch Reglement (HIR)/Renewed Indonesian Regalement (RIB) S. 1848 No. 16, S.1941 No. 44, Pasal 118 /Rechtsreglement Buiten Gewesten (RBG) S. 1927 No. 227, Article 142.” .

[20] V. Swislyn and U. Narsudin, Where Will My Wealth Go? Jakarta: PT. Elex Media Komputindo. 